\title{
Do the stump knotting technique and specimen retrieval method effect morbidity in laparoscopic appendectomy?
}

\author{
Cihan Ağalar, M.D.,' $\odot$ Zekai Serhan Derici, M.D., ${ }^{1}$ Ali Durubey Çevlik, M.D., ${ }^{1}$ \\ Süleyman Özkan Aksoy, M.D., ${ }^{1}$ Tufan Egeli, M.D., 1 ำ Nilay Boztaş, M.D., ${ }^{2}$ \\ \ücahit Özbilgin M.D., ${ }^{1}$ @ Sülen Sarıoğlu, M.D., ${ }^{3}$ @ Tarkan Ünek, M.D. ${ }^{1}$
}

\begin{abstract}
1'Department of General Surgery, Dokuz Eylül University Faculty of Medicine, İzmir-Turkey
${ }^{2}$ Department of Anesthesiology and Reanimation, Dokuz Eylül University Faculty of Medicine, Izmir-Turkey

${ }^{3}$ Department of Pathology, Dokuz Eylül University Faculty of Medicine, Izmir-Turkey
\end{abstract}

\begin{abstract}
BACKGROUND: Stump closure is the most important part of a laparoscopic appendectomy (LA). Closing the appendix base with knot tying is the most cost-effective method. The defined risk factor for surgical site infection (SSI) after LA is the contamination of trocar entry area by inflamed appendicitis. This study aims to compare the single and double knot technique for stump control and specimen removal methods in LA.
\end{abstract}

METHODS: The data of patients who underwent LA between January 2015 and January 2017 were obtained from prospectively collected database. Single and double knot technique, specimen removal method, operation duration, hospital stay, and perioperativepostoperative complications were compared.

RESULTS: Extracorporeal double knot was used in 134 patients (63\%), and single knot was used in 79 patients (37\%). There was no difference between operation duration in the two groups $(p=0.97)$. No stump leakage was observed in any patient. Intraabdominal abscess developed in three patients (1.4\%). Appendix was removed from the abdomen directly in $10 \mathrm{I}$ patients (47\%) and using specimen retrieval bag in 1 I 2 (53\%). SSI developed in five patients (2.3\%), and appendices of all of these five patients were removed from abdomen without using specimen retrieval bag. No SSI was detected in the group that used the specimen retrieval bag $(p=0.02)$.

CONCLUSION: Single or double knot(s) tying can be defined as safe and cost-effective stump closure method. The risk of developing SSI can be reduced using specimen retrieval bag.

Keywords: Extracorporeal knot tying; laparoscopic appendectomy; Specimen retrieval bag; stump; surgical site infection.

\section{INTRODUCTION}

Laparoscopic appendectomy (LA) was first performed by Semm in 1983; and since then, it has been widely used for minimally invasive treatment for acute appendicitis. ${ }^{[1]}$ Nowadays, LA is the standard method in many centers.

Laparoscopic appendectomy has advantages such as less postoperative pain, shorter hospital stay, better cosmetic results, lower wound infection risk, and faster return to normal bowel function than open appendectomy. ${ }^{[2-4]}$ Potential disadvantages are high cost, ${ }^{[5]}$ long operation duration, especially during the learning curve, and encounter of more frequent intraabdominal abscess. ${ }^{[2,3,6-8]}$

The most feared complication of LA is the fistula or intraabdominal sepsis that develops secondary to stump leaks. Several methods have been described to close the appendix stump such as endostapler, endoloop, clip, extracorporeal or intracorporeal knot tying, and stump transection with bipolar

Cite this article as: Ağalar C, Derici ZS, Çevlik AD, Aksoy SÖ, Egeli T, Boztaş N, et al. Do the stump knotting technique and specimen retrieval method effect morbidity in laparoscopic appendectomy? Ulus Travma Acil Cerrahi Derg 2019;25:34-38.

Address for correspondence: Cihan Ağalar, M.D.

Dokuz Eylül Üniversitesi Tıp Fakültesi Hastanesi, Genel Cerrahi Anabilim Dalı, İnciraltı, Balçova, 35320 İzmir, Turkey.

Tel: +90 232 - 4122918 E-mail: cihan.agalar@deu.edu.tr

Ulus Travma Acil Cerrahi Derg 2019;25(I):34-38 DOI: 10.5505/tites.2018.90382 Submitted: 12.02.2018 Accepted: 14.08.2018 Online: 24.10.2018

Copyright 2019 Turkish Association of Trauma and Emergency Surgery 
or ligation devices. But these methods have not been demonstrated to be superior to each other in terms of effectiveness or safety. ${ }^{[4,9-17]}$ Knot tying has cost advantages over other methods, but there is no consensus about tying method (single or double) in literature.

The defined risk factor for surgical site infection (SSI) after LA is the contamination of trocar entry area by inflamed appendicitis. ${ }^{[18-20]}$

This study aims to compare the single and double extracorporeal knot technique for stump closure and specimen retrieval methods used in LA.

\section{MATERIALS AND METHODS}

Patients who underwent LA with diagnosis of acute appendicitis between January I, 2015, and January I, 2017, were included to the study. Patients with incomplete data and those who underwent interval or open appendectomy were excluded from the study.

Detailed information about laparoscopic and open appendectomy was given to all patients before surgery, and their written informed consent was obtained. Approval was taken from the local ethical committee for this study (date: November 26, 2017; decision no: 2017/25-36).

Acute appendicitis was diagnosed in patients who presented with abdominal pain to emergency service or polyclinic; with anamnesis, physical examination, complete blood test, and if necessary, abdominal ultrasonography (US) or computed tomography (CT) was used.

Operations were performed under general anesthesia; all patients received a single dose of first-generation cephalosporin prophylaxis. After Foley catheter insertion, three trocars were placed, $11 \mathrm{~mm}$ below the umbilicus, $5 \mathrm{~mm}$ above the pubis, and depending on the surgeon's preference 5 or 11 $\mathrm{mm}$ to the left side of the patient. In all operations, reusable trocars and reusable laparoscopic hand instruments were used. Inflammatory appendicitis defined as uncomplicated, gangrenous, or perforated appendicitis was defined as complicated appendicitis. ${ }^{[2]}$ High-frequency bipolar coagulation devices were used for dissection and sealing of the mesoappendix. The base of the appendix tied with single or double extracorporeal sliding knot and appendix was cut above the knot(s). The Duncan sliding knot technique (Fig. I) ${ }^{[2]}$ and $150-\mathrm{cm} 2.0$ polyglactin non-needle suture were used in each operation.

All participant surgeons used either the single or double tying method. The choice of single or double knot method is randomly determined, regardless of the patient's clinic, complicated or uncomplicated appendicitis, and the diameter of appendix base.

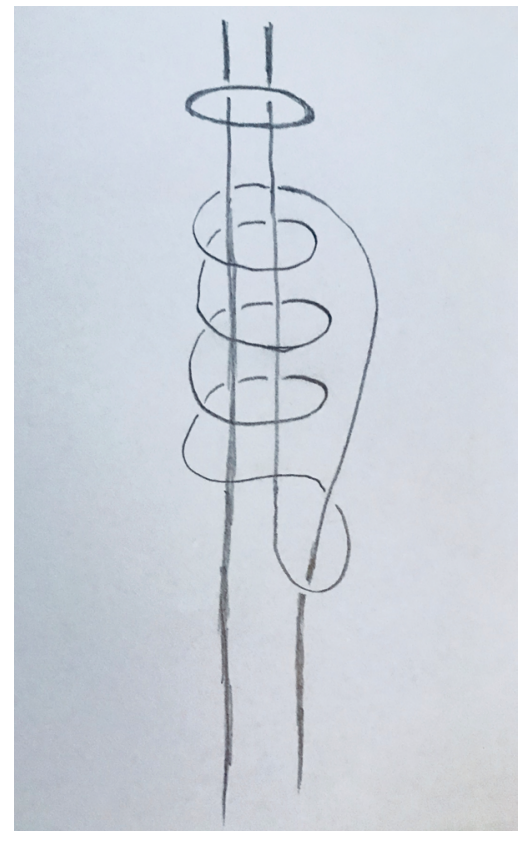

Figure 1. Duncan extracorporeal sliding knot method.

The specimen was removed from the abdomen through the umbilical trocar with (Fig. 2) or without using specimen retrieval bag. The four-quadrant abdominal irrigation was performed for patients with perforated appendicitis, and silicon drain was placed to pelvis.

Patient's age, sex, radiologic examinations, severity of appendicitis (inflamed, gangrenous, perforated, etc.), appendix base diameter, stump closure method, specimen retrieval method, operation duration, hospital stay, perioperative complications, and histopathologic findings were analyzed from the prospectively collected database. Complications were classified according to Clavien-Dindo (C-D) classification system. ${ }^{[23]}$

All statistical analyses were performed using SPSS 16.0 statistical package (SPSS, Chicago, III). Independent samples t-test was used to compare normally distributed continuous variables. The non-normally distributed variables were compared with using the Mann-Whitney $U$ test. Chi-square test was used for comparison of categorical data, and $p<0.05$ was considered as statistically significant.

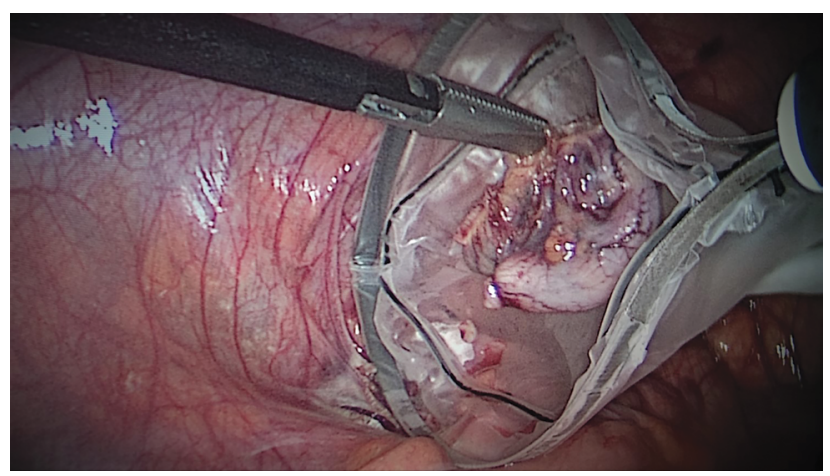

Figure 2. Specimen retrieval method using specimen bag. 


\section{RESULTS}

Between January I, 2015, and January I, 2017, 213 consecutive patients [98 male (46\%) and II5 female (54\%)] were included in the study. The median age of patients was 33.5 \pm 13.77 (range: 16-82) years. Ultrasonography was used in 79 patients (37\%), CT in $109(51 \%)$, and physical examination and complete blood count in 25 (12\%).

Complicated appendicitis was detected in 49 patients (23\%) [30 perforated appendicitis (14\%) and 19 (9\%) gangrenous appendicitis], inflamed appendicitis in 156 (73\%), and no inflammatory sign in 8 (4\%). The median appendix base diameter was $86.4 \pm 24.7 \mathrm{~mm}$ (range 40-170). Extracorporeal double knot was used in 134 patients (63\%), and single knot was used in 79 patients (37\%). The median operation duration was recorded as 44.5 \pm 10.2 (range 20-99) min. The median operation duration in the single and double knot groups was $44.58 \pm 6.73$ and $44.53 \pm 11.94 \mathrm{~min}$, respectively. There was no statistically significant difference between operation duration ( $p=0.97$, independent samples $t$-test). Appendix was removed from the abdomen directly in $10 \mathrm{I}$ patients $(47 \%)$ and using specimen retrieval bag in 112 patients (53\%).

The median hospitalization duration was $2.7 \pm 1.9$ (range: I-16) days. No stump leakage was observed in any patient during postoperative follow-up. Intraabdominal abscess developed in three patients ( $1.4 \%$ ); two of them were treated with interventional radiological methods, and the last patient underwent laparoscopic re-operation (2 C-D Grade IIIA; I C-D Grade IIIB). These three patients had perforated appendicitis. The rate of intraabdominal abscess in perforated group was $10 \%(3 / 30)$.

SSI developed in five patients (2.3\%). Appendices of these five patients were removed from the abdomen without using specimen retrieval bag. No SSI was detected in the group that used the specimen retrieval bag ( $p=0.02$; Fisher's exact test). The mean hospital stay of patients with and without SSI was $7.8 \pm 3.96$ and $2.8 \pm 1.69$ days, respectively. The hospitalization period of patients with SSI was significantly longer $(p<0.00$ I; Mann-Whitney $U$ test). Patient demographics, operation, and follow-up data are summarized according to stump closure methods in Table I.

\section{DISCUSSION}

The debate on two topics continues in the stump closure methods in LA: the cost and the safety. The ideal method for the stump closure should be safe, technically easy, and costeffective. Endostaplers, clips, commercial endoloops, and intracorporeal or extracorporeal tying are the most commonly used methods in LA. Several experimental and clinical studies about using bipolar coagulation devices for stump closure have been published, ${ }^{[24,25]}$ but these devices have not been routinely used for stump control. Endostapler has some advantages

Table I. Patient demographics, operation, and follow-up data

\begin{tabular}{|c|c|c|c|}
\hline Stump closure method & Single knot & Double knot & All patients \\
\hline & $79(37 \%)$ & $134(63 \%)$ & 213 \\
\hline \multicolumn{4}{|l|}{ Sex } \\
\hline Male & 36 & 62 & 98 \\
\hline Female & 41 & 74 & 115 \\
\hline Age (mean $\pm S D)$ & $33.91 \pm 14.78$ & $33.32 \pm 13.2$ & $33.5 \pm 13.77$ \\
\hline \multicolumn{4}{|l|}{ Status of appendix, n (\%) } \\
\hline Complicated & $9(11.4)$ & $40(29.9)$ & $49(23)$ \\
\hline Uncomplicated & $67(84.8)$ & $89(66.4)$ & $156(73)$ \\
\hline No inflammation & $3(3.7)$ & $5(3.7)$ & $8(4)$ \\
\hline Median appendix base diameter $(\mathrm{mm}),($ mean $\pm S D)$ & $82.4 \pm 26.7$ & $87.2 \pm 29.6$ & $86.4 \pm 24.7$ \\
\hline Perforation, n (\%) & $4(5)$ & $26(19)$ & $30(14)$ \\
\hline Operation time (minutes), (mean $\pm S D$ ) & $44.58 \pm 6.73$ & $44.53 \pm 11.94$ & $44.5 \pm 10.2$ \\
\hline \multicolumn{4}{|l|}{ Using specimen retrieval bag, $n(\%)$} \\
\hline No & $57(72.2)$ & $44(32.8)$ & 101 (47) \\
\hline Yes & $22(27.8)$ & $90(67.2)$ & $112(53)$ \\
\hline Surgical site infection, n (\%) & $\mathrm{I}(\mathrm{I} .2)$ & $4(3)$ & $5(2.3)$ \\
\hline Intraabdominal abscess, n (\%) & $0(0)$ & $3(2.2)$ & $3(1.4)$ \\
\hline Median hospital stay (days), (mean \pm SD) & $2.85 \pm 2.02$ & $2.69 \pm 1.84$ & $2.7 \pm 1.9$ \\
\hline
\end{tabular}

SD: Standard deviation. 
such as ease of use and rapidity, which are preferred when the appendix base is necrotic and/or perforated, ${ }^{[4]}$ the high cost, and the $12 \mathrm{~mm}$. Trocar requirement is seen as a disadvantage.

Prospective studies about titanium and polymer clips have been published. The stump closure with both types of clips has been evaluated as practical and safe, but there are concerns about using clip when the appendix base is large and/or inflammation is intense. ${ }^{[2,27]}$

Tying the appendix base with standard non-needle suture is the most cost-effective method in all these stump closure methods. Closing the appendix base with knots is considered as safe as compared to other stump closure methods in various series ${ }^{[9-11,14,28]}$ Single knot ${ }^{[9]}$ and double knot technique ${ }^{[14]}$ were used for closing the appendix stump in some studies, but there is no study in the literature that compares the single or double knot(s). In our study, no difference was observed in the median operation duration and stump safety in single or double knot(s) tying methods. In the light of these data and the literature, single or double knot(s) tying can be defined as safe and cost-effective stump closure method in the laparoscopic treatment of complicated or uncomplicated appendicitis.

The incidence of SSI after LA has been reported between $2.8 \%$ and $12.8 \% .^{[18,19]}$ The use of specimen retrieval bag reduces the ratio of SSI after LA. ${ }^{[20]}$ We obtained similar results with the literature; all of the five patients who developed SSI, their appendix were removed from the abdomen without using specimen retrieval bag. On the other hand, no SSI was observed in any of the patients in the group that used specimen retrieval bag. The risk of developing SSI, which is one of the factors that reduces the advantages of laparoscopic method, extends the length of hospital stay, which can be reduced with use of specimen retrieval bag in LA.

The risk of developing intraabdominal abscess after appendectomy is related to the presence of perforation, and it is more common in LA than in open appendectomy. ${ }^{[8,29]}$ Patients with perforated appendicitis can be safely treated by LA, despite the risk of developing intraabdominal abscess. In our series, intraabdominal abscess was detected in three patients. All of these patients had perforated appendicitis. The risk of intraabdominal abscess can be reduced by four-quadrant irrigation. ${ }^{[30]}$ We performed routine four-quadrant washout in perforated patients, this may explain our $10 \%$ intraabdominal abscess rate after LA in patients with perforated appendicitis, which reaches $24 \%$ in the literature. ${ }^{[8]}$

The major limitations of our study are its retrospective design and no cost analysis. Our study includes the results of single center with heterogeneous surgeon group.

\section{Conclusion}

In conclusion, during LA, single or double knot tying method can be safely used for stump closure in complicated or uncomplicated appendicitis. Our study shows that using the specimen retrieval bag reduces the SSI in LA, but further prospective multicenter studies evaluating the costs are needed.

\section{Conflict of interest: None declared.}

\section{REFERENCES}

1. Semm K. Endoscopic appendectomy. Endoscopy 1983;15:59-64.

2. Guller U, Hervey S, Purves H, Muhlbaier LH, Peterson ED, Eubanks $\mathrm{S}$ et al. Laparoscopic versus open appendectomy: outcomes comparison based on a large administrative database. Ann Surg 2004; 239:43-52

3. Yaghoubian A, Kaji AH, Lee SL. Laparoscopic versus open appendectomy: outcomes analysis. Am Surg 2012;78:1083-6.

4. Mayir B, Ensari CÖ, Bilecik T, Aslaner A, Oruç MT. Methods for closure of appendix stump during laparoscopic appendectomy procedure. Turk J Surg 2015;31:229-31. [CrossRef]

5. Long KH, Bannon MP, Zietlow SP, Helgeson ER, Harmsen WS, Smith $\mathrm{CD}$, et al; Laparoscopic Appendectomy Interest Group. A prospective randomized comparison of laparoscopic appendectomy with open appendectomy: Clinical and economic analyses. Surgery 2001;129:390-400.

6. Rashid A, Nazir S, Kakroo SM, Chalkoo MA, Razvi SA, Wani AA. Laparoscopic interval appendectomy versus open interval appendectomy: a prospective randomized controlled trial. Surg Laparosc Endosc Percutan Tech 2013;23:93-6. [CrossRef]

7. Tanaka S, Kubota D, Lee SH, Oba K, Matsuyama M. Effectiveness of laparoscopic approach for acute appendicitis. Osaka City Med J 2007;53:1-8

8. Krisher SL, Browne A, Dibbins A, Tkacz N, Curci M. Intra-abdominal abscess after laparoscopic appendectomy for perforated appendicitis. Arch Surg 2001;136:438-41. [CrossRef]

9. Nadeem M, Khan SM, Ali S, Shafiq M, Elahi MW, Abdullah F, et al. Comparison of extra-corporeal knot-tying suture and metallic endo-clips in laparoscopic appendiceal stump closure in uncomplicated acute appendicitis. International Journal of Surgery Open 2016;2:11-4. [CrossRef]

10. Arcovedo R, Barrera H, Reyes HS. Securing the appendiceal stump with the Gea extracorporeal sliding knot during laparoscopic appendectomy is safe and economical. Surg Endosc Other Interv Tech 2007;21:1764-7.

11. Bali I, Karateke F, Özyazıcı S, Kuvvetli A, Oruç C, Menekşe E, Emir S, Özdoğan M. Comparison of Intracorporeal Knotting and Endoloop for Stump Closure in Laparoscopic Appendectomy. Ulus Travma Acil Cerrahi Derg 2015;21:446-9. [CrossRef]

12. Blake L, Som R. Best evidence topic: What is the best management of the appendix-stump in acute appendicitis: Simple ligation or stump invagination? Int J Surg 2015;24:20-3. [CrossRef]

13. Kazemier G, in't Hof KH, Saad S, Bonjer HJ, Sauerland S. Securing the appendiceal stump in laparoscopic appendectomy: Evidence for routine stapling? Surg Endosc Other Interv Tech 2006;20:1473-6. [CrossRef]

14. Mayir B, Bilecik T, Ensari CO, Oruc MT. Laparoscopic appendectomy with hand-made loop. Wideochir Inne Tech Malo Inwazyjne 2014;9:152-6. [CrossRef]

15. Rakić M, Jukić M, Pogorelić Z, Mrklić I, Kliček R, Družijanić N, et al. Analysis of endoloops and endostaples for closing the appendiceal stump during laparoscopic appendectomy. Surg Today 2014;44:1716-22.

16. Rickert A, Bönninghoff R, Post S, Walz M, Runkel N, Kienle P. Appendix stump closure with titanium clips in laparoscopic appendectomy. Lan- 
genbeck's Arch Surg 2012;397:327-31. [CrossRef]

17. Shaikh FM, Bajwa R, McDonnell CO. Management of appendiceal stump in laparoscopic appendectomy--clips or ligature: a systematic review and meta-analysis. J Laparoendosc Adv Surg Tech A 2015;25:21-7.

18. Cho M, Kang J, Kim IK, Lee KY SS. Underweight body mass index as a predictive factor for surgical site infections after laparoscopic appendectomy. Yonsei Med J 2014;55:1611-6. [CrossRef]

19. Suh YJ, Jeong SY, Park KJ, Park JG, Kang SB, Kim DW, et al. Comparison of surgical-site infection between open and laparoscopic appendectomy. J Korean Surg Soc 2012;82:35-9. [CrossRef]

20. Lasheen AE, Elaziz OA, Elaal SA, Alkilany M, Sieda B, Alnaimy T. Surgical Wound Infections After Laparoscopic Appendectomy With or Without Using Reusable Retrieval Bag: A Retrospective Study. J Minim Invasive Surg Sci 2016;5:e36894. [CrossRef]

21. Yau KK, Siu WT, Tang CN, Yang GP, Li MK. Laparoscopic Versus Open Appendectomy for Complicated Appendicitis. J Am Coll Surg 2007;205:60-5. [CrossRef]

22. Lo IK, Burkhart SS, Chan KC, Athanasiou K. Arthroscopic knots: determining the optimal balance of loop security and knot security. Arthroscopy 2004;20:489-502. [CrossRef]

23. Clavien PA, Barkun J, de Oliveira ML, Vauthey JN, Dindo D, Schulick $\mathrm{RD}$, et al. The Clavien-Dindo classification of surgical complications: five-year experience. Ann Surg 2009;250:187-96. [CrossRef]
24. Aslan A, Karaveli C, Elpek O. Laparoscopic appendectomy without clip or ligature. An experimental study. Surg Endosc 2008;22:2084-7.

25. Khanna S, Khurana S, Vij S. No clip, no ligature laparoscopic appendectomy. Surg Laparosc Endosc Percutan Tech 2004;14:201-3. [CrossRef]

26. Partecke LI, Kessler W, Von Bernstorff W, Diedrich S, Heidecke CD, Patrzyk M. Laparoscopic appendectomy using a single polymeric clip to close the appendicular stump. Langenbecks Arch Surg 2010;395:107782. [CrossRef]

27. Rickert A, Krüger CM, Runkel N, Kuthe A, Köninger J, Jansen-Winkeln $B$, et al. The TICAP-Study (titanium clips for appendicular stump closure): A prospective multicentre observational study on appendicular stump closure with an innovative titanium clip. BMC Surg 2015;15:85.

28. Ates M, Dirican A, Ince V, Ara C, Isik B, Yilmaz S. Comparison of intracorporeal knot-tying suture (polyglactin) and titanium endoclips in laparoscopic appendiceal stump closure: a prospective randomized study. Surg Laparosc Endosc Percutan Tech 2012;2:226-31. [CrossRef]

29. Fleming FJ, Kim MJ, Messing S, Gunzler D, Salloum R, Monson JR. Balancing the risk of postoperative surgical infections: a multivariate analysis of factors associated with laparoscopic appendectomy from the NSQIP database. Ann Surg 2010;252:895-900. [CrossRef]

30. Hussain A, Mahmood H, Nicholls J, El-Hasani S. Prevention of intra-abdominal abscess following laparoscopic appendicectomy for perforated appendicitis: A prospective study. Int J Surg 2008;6:374-7.

\title{
ORİJINAL ÇALIŞMA - ÖZET
}

\section{Laparoskopik apendektomide güdük bağlama tekniği ve spesimen çıkarma metodu morbiditeyi etkiliyor mu?}

\section{Dr. Cihan Ağalar, ${ }^{1}$ Dr. Zekai Serhan Derici, ${ }^{1}$ Dr. Ali Durubey Çevlik, ${ }^{1}$ Dr. Süleyman Özkan Aksoy, Dr. Tufan Egeli, ${ }^{1}$ Dr. Nilay Boztaş, ${ }^{2}$ Dr. Mücahit Özbilgin, ${ }^{1}$ Dr. Sülen Sarıoğlu, ${ }^{3}$ Dr. Tarkan Ünek}

\author{
'Dokuz Eylül Üniversitesi Tıp Fakültesi, Genel Cerrahi Anabilim Dalı, İzmir \\ ${ }^{2}$ Dokuz Eylül Üniversitesi Tıp Fakültesi, Anesteziyoloji ve Reanimasyon Anabilim Dalı, İzmi \\ ${ }^{3}$ Dokuz Eylül Üniversitesi Tıp Fakültesi, Patoloji Anabilim Dalı, İzmir
}

AMAÇ: Güdük kapatılması laparoskopik apendektominin (LA) en önemli aşaması olarak görülmektedir. Güdüğün dikiş ile kapatılması maliyet açısından en etkin yöntemdir. LA sonrası yara yeri enfeksiyonu gelişmesi için tanımlanmış risk faktörü, trocar giriş alanının inflame apendiks ile kontamine olmasıdır. Bu çalışmanın amacı apendiks güdüğü kapatılmasında tek-çift bağlama teknikleri ve spesimen çıkarma yöntemlerinin karşılaştırılmasıdır. GEREÇ VE YÖNTEM: Ocak 2015 ve Ocak 2017 tarihleri arasında ameliyat edilen hastalara ait bilgiler ileriye dönük olarak doldurulan veritabanının geriye dönük olarak incelenmesi ile elde edildi. Tek-çift bağlama teknikleri, spesimen çıkarma yöntemleri, ameliyat süresi, hastane kalış süresi, perioperative ameliyat sonrası komplikasyonlar karşılaştırıldı.

BULGULAR: Yüz otuz dört hastada (\%63) ekstracorporeal çift bağlama, 79 hastada (\%37) ekstracorporeal tek bağlama ile güdük kapatıldı. İki grupta ameliyat süreleri arasında fark saptanmadı ( $p=0.97)$. Hiçbir hastada güdük kaçağı gelişmedi. Üç hastada (\%।.4) intraabdominal apse gelişti. Yüz bir hastada (\%47) apendiks direkt yöntemle çıkarıldı, I I 2 hastada (\%53) ise spesimen torbası kullanıldı. Beş hastada yara enfeksiyonu gelişti (\%2.3), bu beş hastanın tümünde spesimen torbası kullanılmamıştı $(p=0.02)$.

TARTIŞMA: Tek veya çift bağlama, güvenli ve uygun maliyetli güdük kapatma yöntemi olarak tanımlanabilir. Spesimen torbası kullanımı ile yara yeri enfeksiyonu gelişme riski azaltılabilir.

Anahtar sözcükler: Cerrahi alan enfeksiyonu; ekstrakorporeal düğüm bağlama; güdük; laparoskopik apendektomi; spesimen torbası.

Ulus Travma Acil Cerrahi Derg 2019;25(I):34-38 doi: 10.5505/tjtes.2018.90382 